\title{
IDENTIFIKASI JENIS-JENIS KUSKUS DI WILAYAH KABUPATEN TAMBRAUW
}

\section{(Cuscus Species Identification Around District of Tambrauw)}

\author{
Salmon Kasi ${ }^{1}$ Meliza S. Worabai ${ }^{1 凶}$ dan Hermanus Warmetan ${ }^{1}$ \\ Jurusan Kehutanan, Fakultas Kehutanan Universitas Papua Manokwari, Papua Barat, \\ 98314. Tlp/Fax: +62986211065. \\ ${ }^{\otimes}$ Penulis Korespondensi: Email: meliza_wrb@yahoo.com \\ Diterima: 20 Sept 2019| Disetujui: 05 Okt 2019
}

\begin{abstract}
Abstrak
Tujuan dari penelitian ini adalah untuk mengidentifikasi jenis kuskus di Kampung Warsnembri guna pengembangan dan pengelolaannya di masa yang akan datang. Objek dalam penelitian ini adalah jenis kuskus dari famili Phalangeridae yang terdapat di Kampung Warsnembri Distrik Mubrani Kabupaten Tambrauw dimana penelitian ini menggunakan metode deskriptif dengan teknik observasi dan survei yang dilakukan pada waktu malam hari. Hasil penelitian menunjukkan bahwa terdapat 6 individu dari 2 spesies kuskus yaitu Phalanger orientalis (sebanyak 4 individu) dan Spilocuscus maculatus (sebanyak 2 individu). Kecenderungan diperolehnya sampel kuskus terindikasi karena berada dekat dengan sumber pakan yang tersebar pada tipe hutan primer dan sekunder. Hal ini juga didukung dengan pola konsumsi daging kuskus yang dibatasi pada komunitas masyarakat di kampung.
\end{abstract}

Kata kunci: Phalangeridaei, jenis kuskus, morfologi, suaka alam, kawasan hutan

\begin{abstract}
This study is focusing on identifying the species of cuscus in Warsnembri village in order to design a better development and management program for the future. The main object is cuscus from Phalangeridae family that is found around Warsnembri village, sub-district of Mubrani, Tambrauw. Descriptive method has been applied through observation and survey at night. The result pointed out six individuals from two species namely Phalanger orientalis (four individuals was discovered) and Spilocuscus maculatus (two individuals was found). The likelihood of the cuscus that was found around the village indicated that the food source was quite available in surrounding forest either in primary or secondary forest area. Besides, there was a restriction of consuming cuscus for its meet, and other body parts which emanated from the local consensus was a glaring indication of increasing population to be easily seen as well.
\end{abstract}

Keywords: Phalangeridaei, cuscus species, morphology, nature conservation, forest area

\section{PENDAHULUAN}

Satwa liar merupakan salah satu kekayaan alam hayati yang berperan penting bagi masyarakat yang tinggal di sekitar hutan. Nilai satwa liar seperti kuskus selain dikonsumsi sebagai sumber protein juga dijual dalam meningkatkan pendapatan masyarakat. Status konservasi 
kuskus di Indonesia dilindungi berdasarkan Undang-Undang No. 5 Tahun 1990 tentang Konservasi Sumber Daya Alam dan Ekosistemnya.

Kuskus berasal dari Famili Phalangeridae dan merupakan marsupial (hewan berkantong) Australia yang penyebarannya cukup luas dimulai dari bagian Timur Indonesia, Papua New Guinea, Cape York hingga Queensland di Australia. Namun secara mendalam mengenai perilaku, penyebaran dan jenisnya belum diketahui secara pasti (Menzies 1991). Disebutkan bahwa dari 11 jenis kuskus yang terdapat di New Guinea dan juga marga Phalanger diwakili oleh kurang lebih 8 jenis kuskus yaitu Phalanger orientalis, $P$. sericeus, $P$. carmelilae, $P$. lullulae, $P$. gymnotis, $P$. vestitus, $P$. permextio dan $P$. matanim (Sinery 2006).

Disamping termasuk satwa mamalia berkantung endemik di Papua, kuskus juga merupakan satwa yang memiliki karakter morfologi yang mempesona dengan wilayah penyebaran terbatas sehingga menjadi dasar penetapannya sebagai satwa yang dilindungi oleh pemerintah melalui S.K. Menteri Pertanian No.247/KPTS/UM/4/1979. Kuskus juga dilindungi oleh Peraturan Pemerintah No. 7 tahun 1999 tentang Pengawetan Jenis Tumbuhan dan Satwa dan secara global dua jenis diantaranya telah terdaftar dalam Apendiks 1 adalah daftar seluruh spesies tumbuhan dan satwa liar yang dilarang dalam segala bentuk perdagangan Internasional.

Hutan di Warsnembri dimanfaatkan oleh masyarakat untuk keperluan pertanian, perkebunan, bahan bangunan dan keperluan lainnya (perahu, pagar dan sumber energi). Kerusakan hutan akibat aktivitas masyarakat dapat mengakibatkan terjadinya fragmentasi habitat kuskus. Kuskus cenderung hidup beradaptasi pada hutan lebat, namun dengan pembukaan hutan menyebabkan kuskus dapat bermigrasi ke wilayah lain. Di samping itu tingginya tingkat perburuan terhadap kuskus disertai dengan laju pembukaan areal hutan yang semakin tinggi di kampung ini dikhawatirkan akan terjadi penurunan populasi kuskus bahkan dapat mengakibatkan kepunahan spesies ini di masa mendatang. Oleh karena itu perlu dilakukan studi mengenai identifikasinjenis-jenis kuskus sebagai informasi dasar dalam upaya pengelolaan yang dapat dilakukan untuk perlindungan dan pelestarian kuskus di Kampung Warsnembri.

Di Kampung Warsnembri sendiri informasi tentang jenis kuskus yang ada belum terdokumentasi dengan baik, oleh karena itu penelitian ini dilakukan untuk mengidentifikasi jenis kuskus yang ada di lokasi penelitian. Penelitian ini bertujuan untuk mengidentifikasi jenis-jenis kuskus yang terdapat di Kampung Warsnembri Kabupaten Tambrauw.

\section{METODE PENELITIAN}

Penelitian ini dilaksanakan di Kampung Warsnembri, Distrik Mubrani Kabupaten Tambrauw dan berlangsung selama satu minggu yakni dari tanggal 2 Januari sampai dengan 8 Januari tahun 2017 dengan objek penelitian berupa jenis kuskus yang tersebar di hutan Warsnembri. Dalam penelitian ini, metode yang digunakan adalah metode deskriptif dengan teknik observasi lapangan. 


\section{Pelaksanaan Penelitian}

Penelitian ini dilaksanakan dalam beberapa tahapan yaitu : pengumpulan informasi awal dan penataan kegiatan lapangan dan survei lapangan. Pengumpulan informasi awal dilakukan berdasarkan hasil wawancara langsung dengan masyarakat di Kampung Warsnembri. Hal ini dimaksudkan untuk mendapatkan informasi mengenai jenis kuskus dan lokasi keberadaan jenis-jenis kuskus di Kampung Warsnembri.

Kegiatan penataan dilakukan bersamasama dengan pengenal lokal berupa pengaturan waktu pengamatan, persiapan alat-alat yang dibutuhkan di lapangan. Hal ini dimaksudkan untuk memudahkan kegiatan di lapangan.

Kegiatan di lapangan difokuskan pada penangkapan dan pengamatan kuskus serta deskripsi habitatnya. Cara penangkapan kuskus yang dilakukan oleh masyarakat Warsnembri yaitu memanggil kuskus mendekati sipemanggil dengan cara meniru suara kuskus, kemudian kuskus ditembak dengan senjata angin atau busur panah.

Guna menghindari kematian kuskus dalam jumlah yang banyak, maka penangkapan kuskus didasarkan pada ketentuan :

1. Kuskus dewasa yang telah dapat dikonsumsi oleh penduduk

2. Penangkapan berulang pada jenis yang sudah tertangkap tidak dibenarkan

3. Waktu efektif penangkapan dimulai pukul 20.00 WIT sampai pukul 04.00 WIT dengan penerangan lampu senter.

Pengamatan ciri morfologi dan habitat kuskus dilakukan pada siang hari dan dicatat pada tally sheet.

\section{Variabel Pengamatan}

Dalam penelitian ini, variabel yang diamati dibagi ke dalam dua kelompok, yaitu : variabel Utama, yakni mencakup morfologi kuskus yang dibedakan pada jenis jantan dan betina.

1. Deskripsi jenis meliputi :

- Warna bulu tubuh ( kepala, dorsal, ventral, kaki, ekor) dan pola warna (polos, bertotol, bergaris) pada bagian tertentu.

- Mata (bentuk dan warna bola mata, warna bulu di sekitar bola mata, pupit saat berkontraksi);

- Keadaan penutupan telinga oleh bulu;

- Panjang ekor yang tertutup oleh bulu dan tidak tertutup oleh bulu;

- Warna dan bentuk permukaan bagian atas dan bawah ekor yang tidak tertutup bulu;

2. Morfometrik (ukuran tubuh).

- Panjang total tubuh dan berat tubuh;

- Jenis kelamin

Variabel pendukung, yaitu mencakup tempat ditemukannya kuskus :

- Habitat dan vegetasi yang dikunjungi objek

- Kondisi hutan (primer, sekunder) yang sering dijumpai kuskus.

- Status Konservasi.

\section{Analisis Data}

Data yang diperoleh di lapangan dianalisis secara deskriptif dan tampilkan dalam bentuk gambar dan tabel.

\section{HASIL DAN PEMBAHASAN}

\section{Jenis - jenis Kuskus Yang Ditemukan}

Berdasarkan penelitian yang dilakukan di Kampung Warsnembri diperoleh 6 individu kuskus yang terdiri dari 2 spesies yaitu Phalanger orientalis dan 
Spilocuscus maculatus. Kedua spesies yang ditemukan termasuk dalam famili Phalangeridae. Famili Phalangeridae memiliki ciri utama berkantong yang terletak di bagian perut dan juga dalam bentuk muka yang bundar, dengan daun telinga yang kecil, serta bulu yang lebat. Selain itu kuskus mempunyai ekor yang panjang dan kuat yang berfungsi sebagai alat untuk berpegang pada saat berpindah dari satu dahan ke dahan yang lainnya. Ekor kuskus juga sebagai senjata pertahanan dengan cara mengaitkan ekornya kuat-kuat pada batang atau cabang pohon.

Keenam individu kuskus tersebut ditemukan juga di dalam kawasan Suaka Margasatwa Warsnembri. Suaka Margasatwa merupakan salah satu suaka margasatwa yang ditetapkan untuk perlindungan/pengawetan penyu berdasarkan Surat Keputusan Menteri Kehutanan dan Perkebunan RI Nomor : 891/Kpts-II/1999, 14 Oktober 1999.

Tabel 1. Jenis kuskus yang ditemukan di Kampung Warsnembri

\begin{tabular}{|c|c|c|c|c|}
\hline No. & Spesies & Famili & Nama lokal & $\begin{array}{c}\text { Jenis } \\
\text { kelamin }\end{array}$ \\
\hline 1. & Phalanger orientalis & Phalangeridae & Mosuf Imneda & Jantan \\
\hline 2. & Phalanger orientalis & Phalangeridae & MosufIjmeg Ahta & Jantan \\
\hline 3. & Phalanger orientalis & Phalangeridae & Mesim & Betina \\
\hline 4. & Phalanger orientalis & Phalangeridae & Mocus Inaveii & Jantan \\
\hline 5 . & Spilocuscus maculatus & Phalangeridae & Meswir Marawa & Jantan \\
\hline 6. & Spilocuscus maculatus & Phalangeridae & Meswir Ifunsurga & Jantan \\
\hline
\end{tabular}

Walaupun penamaan secara ilmiah disebutkan terdapat dua spesies namun kuskus yang terdapat di Kampung Warsnembri yang dikenal masyarakat lokal Mpur hanya ada empat jenis. Dari hasil diskusi, masyarakat membedakan atau memberi penamaan Mosuf Imneda berdasarkan atau di lihat dari warna bulu tubuhnya putih semua. Sedangkan penamaan Mosuf Ijmeg Ahta di lihat dari warna bulu putih semua tapi ada garis dorsal tengah yang gelap memanjang dari bagian dahi sampai ekor dan bagian distal ekor tidak mempunyai bulu. Dan untuk habitat masyarakat mengatakan tidak di lihat dari segi habitatnya namun penamaan berdasarkan warna bulu tubuh kuskus, karena spesies Phalanger orientalis tersebut dan tidak berpengaruh memiliki habitat tetap dan cenderung selalu berpindah. Untuk penamaan kuskus betina yaitu Mesim juga di lihat dari warna bulu, dan penamaan untuk kuskus Mocus Inavei di lihat dari warna bulu. Sedangkan Meswir Marawa dan Meswir Ifunsurga juga di lihat dari warna bulu tubuh bintik-bintik atau totol hitam pada punggung, merah dan putih pada tubuh. Selain pengamatam warna dan pola warna bulu tubuh kuskus juga dilakukan pengukuran berat dan panjang tubuh dari ke-6 jenis kuskus yang teridentifikasi.

\section{Ukuran Tubuh Kuskus}

Dari hasil identifikasi menunjukkan bahwa kuskus coklat biasa/kuskus timor $(P$. orientalis) yang dikenal oleh penduduk lokal dalam bahasa Meyah dengan sebutan mesim (betina), mocus inavei (jantan) dan mosuf (jantan). Kuskus bertotol biasa (S. Maculatus) dikenal dengan sebutan meswir yang meliputi meswir oja (betina) tidak di 
jumpai di lokasi penelitian. Sedangkan meswir marawa ona (jantan) di temukan. Kuskus coklat biasa ( $P$. orientalis) merupakan jenis kuskus berukuran sedang dan sering dijumpai di kawasan Suaka Margasatwa Warsnembri. Warna bulu dan ukuran tubuh jenis ini menjadi karakter morfologi pembeda spesies ini. Panjang dan berat tubuh jantan masingmasing berkisar antara $102 \mathrm{~mm}$ sampai $200 \mathrm{~mm}$ dan 3,46 geam sampai 3,50 gram, sedangkan panjang dan berat tubuh betina berkisar antara 75,6 $\mathrm{mm}$ sampai 80 $\mathrm{mm}$ dan 1,77 gram - 2 gram. Dibandingkan dengan hasil karakterisasi Flannery (1994b) terhadap jantan dewasa $P$. orientalis asal daratan New Guinea, Warmetan (2004) asal pulau Yapen, Jandewoa (2005) asal pulau Biak dan Sinery (2006) asal Taman Wisata Gunung Meja Manokwari. Tampak bahwa rerata ukuran tubuh P.orientalis dari yang terbesar berturut-turut yaitu P.orientalis asal Suaka Margasatwa Warsnembri, selanjutnya dari daratan New Guinea, pulau Moor, pulau Biak, pulau Yapen dan Taman Wisata Gunung Meja. Berat tubuh berturut-turut dari dataran New Guinea selanjutnya kawasan Suaka Margasatwa Warsnembri, Taman Wisata Gunung Meja, pulau Yapen, pulau Moor dan pulau Biak. Sedangkan rerata ukuran tubuh betina P.orientalis yang terbesar berturut-turut P.orientalis dari dataran New Guinea, selanjutnya dari kawasan Suaka Margasatwa Warsnembri, Taman Wisata Gunung Meja, pulau Yapen, dan dan asal pulau Biak dengan berat tubuh berturut-turut P.orientalis dari pulau Yapen, selanjutnya daratan New Guinea, kawasan Suaka Margasatwa Warsnembri dan pulau Biak. Hal ini menunjukkan adanya perbedaan ukuran organ dan berat tubuh jantan dan betina P.orientalis pada masing-masing wilayah sebagai akibat variasi geografi, habitat ketersedian pakan dan proses evolusi yang dipengaruhi faktor genetik dalam waktu yang panjang serta perubahan lingkungan.

Sedangkan menurut (Sinery 2006), jenis kuskus yang dijumpai di hutan Wisata Gunung Meja Manokwari. Dengan ukuran panjang dan berat tubuh jantan masing-masing berkisar antara 397 mm sampai $480 \mathrm{~mm}$ dan 2.300 gr sampai 2.500 gr, sedangkan panjang dan berat tubuh betina berkisar antara $374 \mathrm{~mm}$ $400 \mathrm{~mm}$ dan $2.000 \mathrm{gr}-2.200 \mathrm{gr}$.

\section{Deskripsi Morfologi Kuskus}

Deskripsi morfologi pada satwa tersebut umumnya ditujukkan untuk menjelaskan morfologi dan karakteristik dari satwa ini. Deskripsi morfologi kuskus yang ditemukan di Warsnembri dapat di rinci sebagai berikut :

\section{Kuskus (Phalanger orientalis)}

a. Nama lokal : Mosuf Imneda (Jantan 1)

Ciri utama tubuh memiliki warna bulu tubuh putih dan bagian bawah leher berwarna kuning, pada bagian dorsal ditengahnya terdapat bulu berwarna hitam membentuk garis lurus dari kepala sampi ke bagian ekor.

Kepala: Bentuk kepala agak bulat, moncong kurang menonjol berwarna putih, telinga ukuran kecil berwarna putih dan sebelah dalam pinna tidak berbulu, mata agak besar dengan pupil berwarna hitam dan disekelilingnya berwarna putih, saat berkontraksi pupil menyempit secara vertikal, pada dahi dijumpai strip berwarna putih.

Dorsal: strip tengah berwarna hitam, bagian anterior berwarna 
hitam menuju ke arah kepala sedangkan bagian posterior menuju ke arah ekor berkurang hingga putih terang.

Ventral: berwarna putih meluas, pada bagian bawah leher terdapat bulu kuning.

depan dan belakang bagian Kaki: atas berwarna putih sedangkan kaki depan dan belakang bagian bawah berwarna putih kotor.

Ekor: berbulu menipis secara teratur menuju ke bagian tak berbulu warna coklat terang dan ekor tak berbulu bagian atas warna putih dan bawah warna putih kotor dan ada bintil kecil, dalam bahasa lokal : Mosuf Imneda Ona (Jantan).

b. Nama lokal : Mosuf Ijmeg Ahta (Jantan 2)

Ciri utama tubuh memiliki warna bulu keabu-abuan dan garis dorsal tengah yang gelap memanjang dari bagian dahi sampai ekor bagian distal.

Kepala: bentuk kepala agak bulat, moncong lebih meruncing berwarna abu muda, telinga mencolok berwarna abu-abuan dan sebelah dalam pinna tidak berbulu, bentuk mata besar dengan pupil berwarna hitam besar dan disekelilingnya berwarna coklat, saat berkontraksi pupil menyempit secara vertikal, pada dahi dijumpai strip berwarna abu tua.

Dorsal: strip tengah berwarna hitam, bagian anterior berwarna hitam menuju ke arah kepala sedangkan bagian posterior menuju ke arah ekor berkurang hingga putih terang.

Ventral: berwarna keabu-abuan dan bentuknya meluas.
Kaki: depan dan belakang bagian atas berwarna abu-abu sedangkan kaki depan dan belakang bagian bawah berwarna abu-abu terang.

Ekor: berbulu menipis secara teratur menuju ke bagian tak berbulu berwarna abu-abu dan ekor tak berbulu bagian atas warna putih dan bawah warna putih kotor, bentuk permukaan ekor tak berbulu bagian atas keriput dan kasar sedangkan bagian bawah berbuku-buku dan halus, dalam bahasa lokal : Mosuf Ijmeg Ahta Ona (Jantan).

c. Nama lokal : Mesim (Betina)

Ciri utama tubuh memiliki warna bulu tubuh kecoklatan dan bulu putih bagian ventral atau perut, garis dorsal tengah yang gelap memanjang dari bagian dahi sampai ekor dan bagian distal ekor.

Kepala: bentuk kepala agak bulat, moncong meruncing berwarna merah gelap, telinga agak kecil berwarna coklat tua dan sebelah dalam pinna tidak berbulu, bentuk mata agak sipit dengan pupil berwarna hitam kecil dan disekelilingnya berwarna coklat, saat berkontraksi pupil menyempit secara vertikal, pada dahi dijumpai strip berwarna hitam.

Dorsal: strip tengah berwarna hitam, bagian anterior berwarna hitam menuju ke arah kepala sedangkan bagian posterior menuju ke arah ekor berkurang hingga coklat.

Ventral: berwarna putih dan berbentuk meluas, terdapat kantong anak.

Kaki: depan dan belakang bagian atas berwarna coklat tua sedangkan 
kaki bagian bawahnya berwarna coklat muda.

Ekor: berbulu menipis secara teratur menuju ke bagian tak berbulu berwarna coklat muda dan ekor tak berbulu bagian atas warna putih kotor dan bawah warna kekuningan tua, bentuk permukaan ekor tak berbulu bagian atas dan bawah sama dengan spesies jantan, dalam bahasa lokal mesim oja (betina).

d. Nama lokal : Mocus Inavei (Jantan 3)

Ciri utama tubuh memiliki warna bulu tubuh keabua-abuan dan bulu putih bagian ventral atau perut, garis dorsal tengah yang gelap memanjang dari bagian dahi sampai ekor dan bagian distal ekor.

Kepala: bentuk kepala agak bulat, moncong meruncing berwarna coklat, telinga agak kecil berwarna coklat muda dan sebelah dalam pinna tidak berbulu, bentuk mata agak sipit dengan pupil berwarna hitam kecil dan disekelilingnya berwarna coklat, saat berkontraksi pupil menyempit secara vertikal, pada dahi dijumpai strip berwarna hitam.

Dorsal: strip tengah berwarna hitam, bagian anterior berwarna hitam menuju ke arah kepala sedangkan bagian posterior menuju ke arah ekor berkurang hingga coklat keabuan.

Ventral: berwarna putih dan berbentuk meluas.

Kaki: depan dan belakang bagian atas berwarna coklat muda sedangkan kaki bagian bawahnya berwarna coklat tua.

Ekor: berbulu menipis secara teratur menuju ke bagian tak berbulu berwarna keabua-abuan dan ekor tak berbulu bagian atas warna putih dan bawah warna putih kotor, bentuk permukaan ekor tak berbulu bagian atas dan bawah halus dan tidak berbuku-buku. Dalam bahasa lokal ialah mocus inavei ona (jantan).

\section{Kuskus (Spilocuscus maculatus)}

a. Nama lokal: Meswir Marawa (Jantan 1)

Ciri utama tubuh memliki warna bulu tubuh kemerah-merahan dan bintik-bintik hitam atau totol bagian tubuh belakang sampai batas pangkal ekor atau distal ekor tidak mempunyai bulu,warna bulu putih bagian ventral atau perut, berbulu lebat, halus dan tipis.

Kepala: bentuk kepala bulat, moncong kurang menonjol, telinga sangat pendek ditutupi bulu dan berwarna coklat kemerahan dan seluruhnya tertutup bulu, sebelah dalam pinna berbulu, dan bentuk mataagak besar dengan pupil berwarna hitam muda dan disekelilingnya warna kemerahan.

Dorsal: warna bulu coklat muda hingga coklat kemerahan, bagian anterior bertotol coklat gelap hingga kemerahan, bagian posterior bertotol hitam yang letaknya tak beraturan dengan latar belakang totol putih kotor.

Ventral: berwarna putih meluas.

Kaki: bagian depan berwarna merah muda dan bagian belakang dijumpai warna coklat kemerahan dengan latar belakang coklat tua.

Ekor: berbulu berwarna putih muda, ekor tak berburu bagian atas dan bawah berwarna merah muda dan bentuk permukaan ekor tak berbulu 

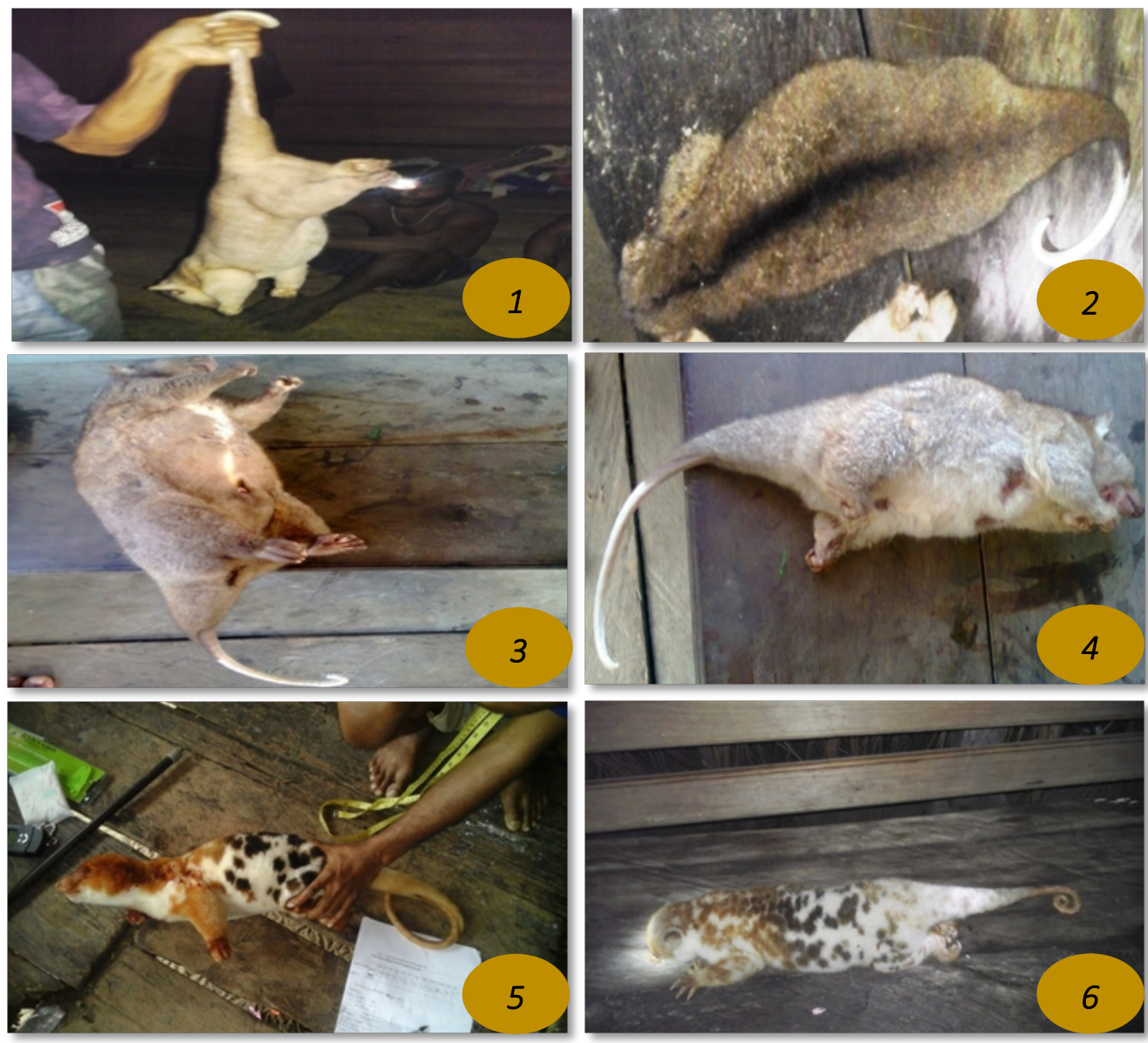

Gambar 1. Jenis dan bentuk morfologi kuskus yang ditemukan pada lokasi penelitian: 1). $P$. orientalis/mosuf imneda; 2). $P$. orientalis/mosuf ijmeg ahta; 3). $P$. orientalis/mesim; 4). P. orientalis/mocus inavei; 5). S. maculatus; 6). $S$. maculatus.

bagian atas halus tapi bagian bawah berbuku-buku dan kasar, dalam bahasa lokal meswir marawa ona (jantan).

b. Nama lokal: Meswir Ifunsurga (Jantan 2)

Ciri utama tubuh memliki warna bulu totol dan bintik-bintik hitam, putih dan merah muda dari bagian tengah dorsal menuju ke arah kepala merah muda dan putih sedangkan bagian tengah dorsal menuju ke arah ekor berwarna bintik-bintik hitam sampai pangkal ekor dan warna bulu putih hingga ekor tidak mempunyai bulu. Kemudian warna bulu putih, berbulu lebat, halus dan tipis.

bentuk kepala bulat, moncong kurang Kepala: menonjol, telinga sangat pendek ditutupi bulu berwarna merah muda dan seluruhnya tertutup bulu, sebelah dalam pinna berbulu, bentuk mata 
agak kecil dengan pupil berwarna coklat muda dan disekelilingnya warna merah muda.

Dorsal: berwarna merah muda hingga putih kemerahan, bagian anterior bertotol merah muda hingga kemerahan, bagian posterior bertotol hitam dan putih yang letaknya tak beraturan dengan latar belakang totol putih abuan.

Ventral: berwarna putih meluas.

Kaki: bagian depan berwarna merah kekuningan dan bagian belakang dijumpai warna coklat kemerahan dengan latar belakang putih kotor.

Ekor: berbulu berwarna putih, ekor tak berburu bagian atas dan bawah berwarna coklat tua dan bentuk permukaan ekor tak berbulu bagian atas halus tapi bagian bawah berbuku-buku dan kasar, dalam bahasa lokal meswir ifunsurga ona (jantan).

\section{Habitat Kuskus}

Berdasarkan pengamatan yang dilakukan bahwa jenis kuskus yang berada di kawasan Suaka Margasatwa Warsnembri dijumpai jenis kuskus berada pada kawasan hutan primer dan sekunder. Definisi hutan primer adalah hutan alam yang telah mencapai umur lanjut dan ciri struktur tertentu yang sesuai dengan kematangannya, serta dengan demikian memiliki sifat-sifat ekologis yang unik. Namun hutan primer terletak cukup jauh jaraknya dari pemukiman penduduk. Sedangkan definisi hutan sekunder menurut Lamprecht (1986), adalah hutan yang tumbuh dan berkembang secara alami sesudah terjadi kerusakan/perubahan pada hutan yang pertama. Jenis kuskus yang dijumpai pada hutan primer biasanya melakukan aktifitas pada malam hari yaitu dari jam 20.00 - 05.00 WIT. Keberadaan kuskus di hutan biasanya pada dahan pohon yang mana cenderung dekat dengan sumber pangan antara lain pada jenis pohon ketapang (Terminalia catappa), matoa (Pometia pinnata), merbau (Intsia sp.), beringin (Ficus sp.), pandan (Pandanus tectorius) dan sirih hutan (Piper acundum).

Dari informasi penduduk setempat bahwa jenis-jenis kuskus di Kampung Warsnembri umumnya menempati kawasan berhutan primer yang jauh dari pemukiman penduduk. Hal ini diduga berkaitan dengan sifat alamiah kuskus yang soliter serta adanya kegiatan berburu oleh masyarakat local sehingga merasa terancam. Jenis kuskus pada kawasan ini umumnya diburu oleh penduduk untuk kebutuhan konsumsi daging sebagai salah satu pemenuhan kebutuhan protein hewani. Dengan demikian, manusia dianggap sebanagi predator utama keberadaan jenis-jenis kuskus pada kawasan ini.

Menzies (1991), menyebutkan bahwa hingga kini habitat kuskus di alam belum banyak diketahui. Jenis Spilocuscus maculatus dan Spilocuscus rufeniger, umumnya hidup pada hutan dataran rendah di utara New Guinea dengan interval ketinggian $0-1.200$ meter dpl. Selain itu, biasanya dijumpai pada hutanhutan primer, namun kadang $S$. maculatus dijumpai pada hutan sekunder, bahkan pada daerah bervegetasi mangrove. Phalanger orientalis biasanya tersebar pada hutan dataran rendah dan hutanhutan perbukitan yang ditumbuhi vegetasi Eucalyptus sp., dengan interval ketinggian 0 - 1500 meter dpl.

Alikodra (1990), mengelompokkan jenis-jenis satwa ke dalam beberapa 
kelompok, seperti binatang air, binatang yang hidupnya tergantung pada air, binatang yang hidupnya kurang tergantung pada air dan binatang yang hidupnya tidak tergantung pada air. Kuskus merupakan jenis satwa yang hidupnya kurang tergantung pada air, sehingga satwa ini umumnya tidak memerlukan tempat/lokasi khusus untuk memperoleh air guna kebutuhan hariannya. Kebutuhan air untuk proses metabolisme tubuh umumnya diperoleh dari jenis-jenis makanannya.

Spilocuscus maculatus jantan (meswir marawa ona) ditemukan pada pohon Intsia bijuga di hutan primer Kampung Warsnembri dengan vegetasi sekitar berupa jenis pohon Barringtonia asiatica, Pandanus tectorius, Ficus sp., dan Intsia palembanica. Sedangkan Phalanger orientalis betina (mesim oja) dan Phalanger orientalis jantan (mocus inavei ona) ditemukan pada pohon Terminalia catappa dan Collophyllum inophyllum di hutan sekunder atau bekas perladangan penduduk di Kampung Warsnembri dengan vegetasi sekitar berupa jenis Macaranga mappa, Alstonia shcollaris dan Piper acundum.

\section{Perburuan dan Pemanfaatan}

Kuskus umumnya di buru oleh penduduk sekitar untuk kebutuhan daging sebagai salah satu sumber protein hewani, dan juga sebagai binatang peliharaan yang dapat dijual (Petocz 1994). Beberapa jenis dari satwa ini kerap diual karena memiliki corak warna pada bulu dibangian tubuhnya yang indah. Tak jarang beberapa jenis bahkan dibunuh dan diawetkan hanya untuk mebutuhan estetika dari jenis kuskus ini, disamping kulit dan bulunya dapat digunakan sebagai bahan baku busana seperti topi, jacket dll (Mackinnon 1986).

Di Timor Barat, Nusa Tenggara Timur, masyarakat setempat mengkonsumsi kuskus jenis Phalanger sebagai sumber pangan (Farida $d k k$. 2001). Hal yang sama juga dijumpai di Papua, kuskus termasuk salah satu jenis hewan yang menjadi sumber protein hewani alternatif. Sehingga dapat disimpulkan bahwa pemanfaatan satwa untuk tujuan dikonsumsi memberikan kontribusi yang signifikan terhadap pemenuhan konsumsi protein hewani masyarakat di daerah pedalaman Papua. Hal ini juga terjadi dalam skala yang lebih luas lagi karena menurut PrescotAllen (1982) sedikitnya ada 62 negara di dunia yang penduduknya memanfaatkan satwa sebagai sumber protein hewani.

Namun, masyarakat Kampung Warsnembri tidak mengijinkan kuskus diambil dalam jumlah besar, karena masyarakat menyadari nilai eksistensi kuskus terhadap kawasan hutan sekitar kampung ini. Agar kuskus dapat berkembangbiak secara alam di hutan Suaka Margasatwa Warsnembri atau di hutan sekitarnya yang menjadi habitat dan menunjang ketersediaan sumber pangan bagi jenis kuskus.

\section{DAFTAR PUSTAKA}

Alikodra HS. 1990. Pengelolaan satwa liar jilid 1. Departemen Pendidikan dan Kebudayaan, Direktorat Jenderal Pendidikan Tinggi, Pusat Antar Universitas Ilmu Hayati, IPB: Bogor.

Farida WR, G Semiadi, Wirdateti dan H Dahruddin. 2001. Pemanfaatan kuskus (Phalanger sp.) oleh masyarakat Timor Barat, Nusa Tenggara Timur. Biota, 6 (2): 85-86. 
Flannery T. 1994b. Possums of the World; A Monograph of the Phalangeroidae. Sidney: Roberth Brouwn \& Asscociates.

Jandewoa. 2005. Eksplorasi jenis kuskus dan habitatnya di Biak Utara Kabupaten Biak Numfor. [Skripsi]: Jurusan Kehutanan Fakultas Pertanian Universitas Negeri Papua (UNIPA). (Tidak diterbitkan).

Lamprecht H. 1989. Silviculture in the tropics: Tropical forest ecosystems and their tree species-possibilities and methods for their long-term utilization. Technical Cooperation-Federal Republic of Germany.

Mackinnon B. 1986. Pricing human life. Science, Technology, and Human $\begin{array}{llll}\text { Values, } & 11 & \text { (2): } & \text { 29-39. }\end{array}$ https://doi.org/10.1177/016224398601 100207.
Menzies JI. 1991. A Handbook of New Guinea marsupials and monotremes. Madang-PNG: Kristen Pres Inc.

Petocz RG. 1994. Mamalia darat Irian Jaya. Jakarta: PT. Gramedia Pustaka Utama.

Prescott-Allen R and Prescott-Allen C. 1982. What's wildlife worth? Washington: International Institute for Environment and Development.

Sinery AS. 2006. Species of cuscus in Taman Wisata Gunung Meja Manokwari Regency, West Irian Jaya. Biodiversitas, 7 (2): 175-180.

Warmetan H. 2004. Eksplorasi jenis kuskus pada Cagar Alam Pulau Yapen Tengah dan Distrik Yapen Selatan Kabupaten Yapen Waropen. [Skripsi]: Jurusan Kehutanan Fakultas Pertanian Universitas Negeri Papua (UNIPA). (Tidak diterbitkan). 